\title{
Microcystic Lymphatic Malformation: A Case Report
}

Yousif I Eltohami, Nour E Alim and Amal H Abuaffan*

University of Khartoum, Al-Gamaa Ave, Khartoum 11111, Sudan

*Corresponding author: Amal H Abuaffan, University of Khartoum, Faculty of dentistry, Sudan, Tel: +249917481188; E-mail: amalabuaffan@yahoo.com

Received date: Feburary 20, 2017; Accepted date: March 06, 2017; Published date: March 13, 2017

Copyright: @ 2017 Eltohami YI, et al. This is an open-access article distributed under the terms of the Creative Commons Attribution License, which permits unrestricted use, distribution, and reproduction in any medium, provided the original author and source are credited.

\begin{abstract}
Lymphatic malformations appear in different parts of the body, but when it rises cervico-facially it would probably be in the oral cavity, it is uncommon in adult, usually appear in infancy and early childhood. This is a case report of lingual lymphatic malformation in a 32 years old Sudanese male treated with hot saline and intra lesion steroids.
\end{abstract}

Keywords: Lymphatic malformation; Lymphangioma; Tongue, Adult; Hot saline; Ttriamcinolone acetnoide

\section{Introduction}

Lymphatic malformations are a congenital malformed lymphatic vessels [1]. It is divided into; the macro cystic type, cysts more than 2 $\mathrm{cm}$ with clear margins, the microcystic type, consisting of cysts less than $2 \mathrm{~cm}$, which has diffuse ill defined margins and the combined type include. Micro cystic type usually found in the oral cavity, throat, the tongue, sub-mandibular gland and parotid gland. It can cause macroglossia, difficulty in breathing and eating [2].

Most of the cases diagnosed directly after delivery, and $90 \%$ are developed before the age of two years [3]. They can appear at many sites but the majority in the head and neck $75 \%$ of which occur in the oral cavity, followed by the oropharynx and the parapharyngeal space [4]. Intraoral, frequently found in the tongue, lips, mucosa buccally, mouth floor and soft palate [5]. Lymphatic malformation appear as a soft tissue tumor that grow slowly with no pain, that depends on the lesion extension. The outer ones appear as pebbly irregular surface with pinkish color though it can be reddish or slight purple if hemorrhages secondarily occur [6], while the deeper ones appear as soft, diffuse lesions with normal color [5].

Treatment of the lymphatic malformations ranged from surgery, radio-therapy, sclerotherapy cryotherapy, steroid injection, electrocautery, embolization, ligation, and laser surgery [7]. This is a case report of lymphatic malformation of the tongue managed by intra lesional steroid injection and hot saline.

\section{Case Scenario}

A 32 years old Sudanese male came to the private dental clinic complaining from painless diffuse firm tongue swelling. The lesion appeared shortly after birth and increased gradually in size. The past medical history, the patient generally fit, without a history of habits consumption. Clinical examination, non tender diffuse firm tongue swelling with rough pebbly telangiectatic surface with salmon egg appearance. There were no hotness, thrills or bruits and no bloody discharge (Figures 1 and 2). Incision biopsy result revealed classic histopathological features of lymphatic malformation with scatter endothelial cells. Treatment, hot normal saline and intra lesional steroid (triamicelone acetnoid $40 \mathrm{mg}$ ) was prescribed one injection weekly for 10 weeks.

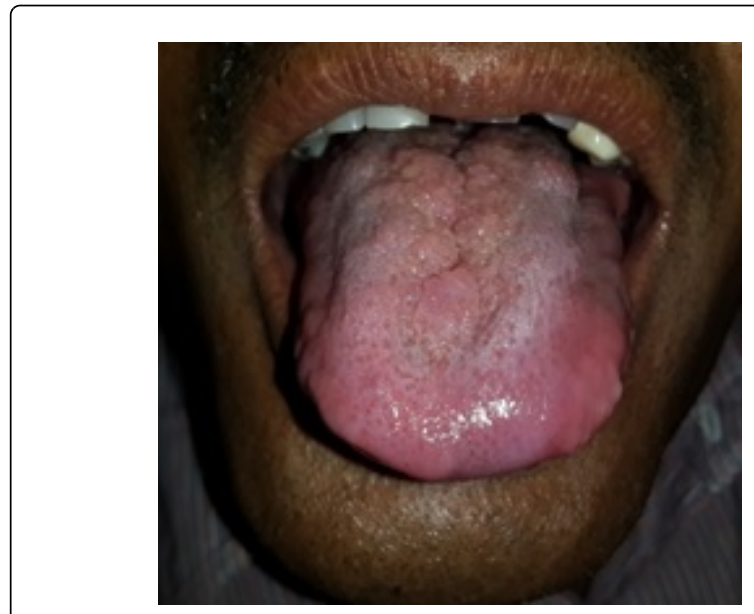

Figure 1: Shows diffuse tongue swelling with rough pebbly surface and salmon eggs appearance.

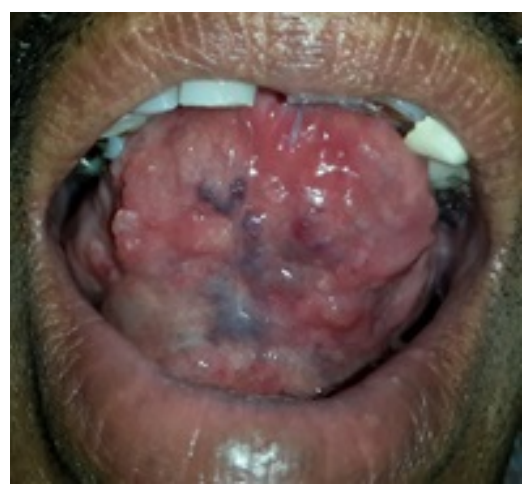

Figure 2: Shows diffuse firm swelling of the ventrum of the tongue with telangiectatic pebbly surface. 


\section{Discussion}

As the lymphatic malformations develop mostly in the head and neck; the tongue found to be the mostly affected site in the oral cavity $[8,9]$. Tongue Lymphatic malformations tend to be microcystic, diffuse with no clear margins in the anterior tongue two-third [10]. It characterized clinically by pebbly shape of the tongue surface due to multiple lymph-filled cysts with a color ranging from transparent to purple [11]. Histological the lymphatic malformations have no difference with regard to their site, they appear as thin cystic dilations lined by endothelial cells and filled with fluid rich in protein [12]. Lymphatic malformation of the tongue has slow growing pattern with periods of dormancy. Repeated infections in respiratory system or trauma can amplify the lymphatic malformation lesion and aggravate it. Tongue swelling can impair the breathing, swallowing, and the speaking [11].

The main aim of lymphatic malformation treatment is to restore and preserve the function and aesthetic integrity [13]. Treatment of lymphatic malformations is difficult; Because they impregnate to the surrounding tissues, specially the microcystic type of tongue lymphatic malformations considered as a challenging one, it can range from surgical excision, sclerotherapy, cryotherapy, electrocautery, corticosteroid injection, and embolization [14,15].

Triamcinolone acetonide is a long acting glucocorticoid, which not only inhibits collagen synthesis but also accelerates collagen degradation, in addition to its ability to repress inflammation [16], also glucocorticoids have hindering effects of tumor lymphangiogenesis [17]. Sclera therapy is commonly the preferred treatment method for vascular malformations [18]. The best-known sclerosant in the United States was hypertonic saline sodium chloride $23.4 \%$. It was nonspecific in cellular destruction it causes dehydration to endothelial cells and red blood cells. Patient's preferred "saline injections," The drug was readily available, lacks allergenicity, and was inexpensive [19].

Boiling water and warm hypertonic saline solutions have been variously used, they act by releasing heat energy that destroys the anomalous vascular tissues. More than boiling water, boiling saline retains heat energy which can adversely affect the vascular endothelial tissues which lead to necrosis and obliteration of the vessels' Lumina, which regularly promotes coagulation and death of the vessels [20]. In this case the combination of the triamcinolone acetonide injections and the hot saline gives satisfactory results without any complications.

The Recurred of the lymphatic malformations after treatment is common because of their infiltration to the surroundings that make it difficult to be managed, in a study by Kasperbauer and Orvidas, the rate of recurrence found to be $39 \%$ and the commonest recurrence site were the tongue and hypo pharynx [21].

\section{Conclusion}

Many ways had been suggested for management of cervico-facial lymphatic malformations, but still it's a challenging problem, surgery is no longer preferred for management of microcystic lymphatic malformations, therefore, intra-lesion steroid injection found to be effective, conservative method for treating tongue lymphangiomas.

\section{References}

1. Cho BC (2016) Cervicofacial Lymphatic Malformations: A Retrospective Review of 40 Cases. Arch Plast Surg 43: 8-10.

2. Elluru RG, Balakrishnan K, Padua HM (2014) Lymphatic malformations: diagnosis and management. Semin Pediatr Surg 23: 178-85.

3. Ikeda H, Fujita S, Nonaka M, Uehara M, Tobita T (2006) Cystic lymphangioma arising in the tip of the tongue in an adult. Int J Oral Maxillofac Surg 35: 274-276.

4. Rickert SM, Diallo AM (2013) Lymphatic Malformations of the Airway. Otolaryngology- Head and Neck Surgery 149: 156-160.

5. Pinto A (2005) Pediatric soft tissue lesions. Dent Clin North Am 49: 241-258.

6. Weiss SW, Goldblum JR (2001) Soft Tissue Tumors. 4th ed. St. Louis: Mosby. Tumors of lymph vessels: 955-967.

7. Hellmann JR, Myer CM, Prenger EC (1992) Therapeutic alternatives in the treatment of life-threatening vasoformative tumors. Am J Otolaryngol 13:48-53.

8. Heether J, Whalen T, Doolin E (1994) Follow-up of complex unresectable lymphangiomas. Am Surg: 840-841.

9. Song TB, Kim CH, Kim SM, Kim YH, Byun JS (2002) Fetal axillary cystic hygroma detected by prenatal ultrasonography: a case report. J Korean MedSci 17: 400-402.

10. Iamaroon A, Pongsiriwet S, Srisuwan S, Krisanaprakornkit S (2003) Lymphangioma of the tongue. Int J Paediatr Dent 13: 62-63.

11. Balakrishnan A, Bailey CM (1991) Lymphangioma of the tongue: a review of pathogenesis, treatment and the use of surface laser photocoagulation. J Laryngol Oto 105: 924-929.

12. Yaita T, Onodera K, Xu H, Ooya K (2007) Histomorphometrical study in cavernous lymphangioma of the tongue. Oral Dis 13: 99-104.

13. Perkins JA, Manning SC, Tempero RM, Cunningham MJ, Edmonds JL (2010) Lymphatic malformation: current cellular and clinical investigations. Otolaryngol Head Neck Surg 142: 789e9.

14. Hellmann JR, Myer CM III, Prenger EC (1992) Therapeutic alternatives in the treatment of life-threatening vasoformative tumors. Am J Otolaryngol 13: 48-53.

15. Giguère CM, Bauman NM, Smith RJ (2002) New treatment options for lymphangioma in infants and children. Ann Otol Rhinol Laryngol 111: 1066-1075.

16. Oh J, Jung YS, Kim GS, Oh IK, Rho BK (2007) The effect of short-term exposure of triamcinolone acetonide on fibroblasts and retinal pigment epithelial cells. Acta Ophthalmol Scand 85: 786e790.

17. Yano A, Fujii Y, Iwai A, Kawakami S, Kageyama Y, Kihara K (2006) Glucocorticoids suppress tumor lymphangiogenesis of prostate cancer cells. Clin Cancer Res 12: 6012e6017.

18. Lee B, Do Y, Byun H, Choo I, Kim D (2003) Advanced management of venous malformation with ethanol sclerotherapy: mid-term results. J Vasc Surg 37: 533-538.

19. Charles LD (2007) Sclerotherapy: Introduction to Solutions and Techniques. Perspectives in Vas Surg End Ther 19: 317-324.

20. Ketan RB, Sunny S, Shahid MN (2006) Histrory of bipolar coagulation. Neurrosurg Rev 29: 93-96.

21. Orvidas LJ, Kasperbauer JL (2000) Pediatric lymphangiomas of the head and neck. Ann Otol RhinolLaryngol 109: 411-421. 